\title{
Effect of NPK fertilizer and microbial consortium to growth and production of garlic (Allium sativum L.)
}

\author{
Eti Heni Krestini ${ }^{1,2}$, Ani Susilawati ${ }^{3 *}$, Catur Hermanto ${ }^{1}$ \\ ${ }^{1}$ Vegetable Research Institute, Jl. Tangkuban Perahu No. 517 Lembang Bandung \\ ${ }^{2}$.Faculty of Agriculture, Padjadjaran University, J1. Bandung Raya Sumedang KM 21, Jatinangor, Sumedang \\ ${ }^{3}$ Indonesian Swamp Agriculture Research Institute(ISARI), Jl. Kebun Karet, Loktabat, Banjarbaru 70712, South Kalimantan
}

\begin{abstract}
Garlic productivity in Indonesia is relatively low due to ecological fitness, agronomic performance, and pest losses. For the reason, the research was objected to study the effect of microbial consortium and NPK fertilizer toward the growth and production of garlic. This research was conducted at the experimental field of the Indonesian Vegetable Research Institute situated at $1.300 \mathrm{~m}$ asl in Lembang - West Jawa - Indonesia from October 2018 until February 2019. The exp eriment was arranged in randomized block design, consisted of 6 treatments, and 3 replications. The treatments were: 1) no microbial consortium + no NPK fertilizer (negative control), 2) no microbial consortium + $50 \%$ NPK fertilizer, 3). no microbial consortium $+100 \%$ NPK recommendation, 4) application of microbial consortium + no NPK, 5) application of microbial consortium $+50 \%$ of NPK recommendation, and 6). Application of microbial consortium $+100 \%$ of NPK recommendation. The results showed that there was no significant effect of NPK fertilizer and the microbial consortium on the growth and production of garlic. However, the application of microbial consortium $+50 \%$ of NPK recommendation performed best on plant height and number of leaves, while application of microbial consortium only resulted in the best pseudostem growth and yield component of garlic.
\end{abstract}

\section{Introduction}

The economic value of garlic throughout the world in recent years has continued to increase so that increasing production and quality of garlic has become the main focus and guidance of farmers and researchers in the world [1]. China occupies the first place as the largest garlic producer in the world, which in 2016 China was able to produce garlic reaching 21,197,131 tons [2]. The high amount of production makes China can export garlic production to other countries and get huge profits. In Indonesia alone, garlic (Allium sativum L.) is one of the leading horticultural commodities that can be strived to become self-sufficient in the next few years. The self-sufficiency program aims to meet the needs of national garlic, reduce imports, and improve farmers' welfare.

One of the problems experienced by farmers is mainly related to the low productivity of garlic in Indonesia. One of the factors is the inaccurate method of fertilizing which will impact on soil fertility and declining yields of farmers. Fertilizer is one of the most important things, so availability is necessary for the sustainability of soil productivity and plants and food security [3]. Kalay et al. [4] states that fertilizer is considered to have a very big role in the crop cultivation system because it can affect the process of improving physical, chemical, and biological soil fertility so that it affects the growth and production of plants.

A fertilizer that is very commonly used by farmers is NPK fertilizer. This fertilizer is included in inorganic fertilizers that contain major nutrients such as nitrogen, phosphorus, and potassium. Chemical fertilizers do not provide carbon compounds that contribute to the improvement of physical and biological properties of the soil, consequently if used incorrectly the soil structure is damaged and soil biological activity will be reduced so that proper and balanced fertilization is recommended to increase the efficiency of fertilizer use and improvement of physical conditions and soil biology.

The addition of biological microbes from organic fertilizer can have a positive impact on plant growth and production. The addition of biological microbes can be given in the form of a consortium. The microbial consortium is a kind of organic fertilizer consisting of a collection of microbes that work together in a group so that it has more ability to degrade an organic compound [5]. The results of the addition of the microbial consortium are the availability of nutrients for plants for metabolic processes, increased soil fertility and quality of crop yields through an increased biological activity that interacts with physical and chemical properties.

The use of microbial consortium combined with NPK fertilizer is long-term sustainable nutrient management that can be beneficial for improving the quality of soil fertility [6]. Research on the response of garlic plants to the use of NPK fertilizer and the addition of a microbial consortium has never been done, therefore this study aims to determine the effect of the use of NPK fertilizer and a microbial consortium on the growth and production of garlic.

This study discusses the use of NPK fertilizer and a microbial consortium on the growth and production of garlic 


\section{Methods}

\subsection{Time and Place of Research}

The research was carried out in the Experimental Garden of Indonesian Vegetable Research Institute at an altitude of $1,300 \mathrm{~m}$ asl in Lembang - West Java Indonesia in October 2018 to February 2019.

\subsection{Procedures}

The study was arranged in a randomized block design (RBD) consisting of 6 treatments and 3 replications. The treatments tested included: 1) without a microbial consortium + without NPK fertilizer (negative control) (M0K0) 2) without a microbial consortium + NPK fertilizer 50\% recommended dosage (M0K1) 3) without a microbial consortium + NPK fertilizer $100 \%$ recommended dosage (M0K2 ) 4) microbial consortium + without NPK (M1K0) 5) microbial consortium + NPK 50\% recommended dosage (M1K1) and 6) microbial consortium $+100 \%$ NPK (M1K2). The data obtained were then analyzed by the Tukey test (BNJ).

\section{Results and Discussion}

Increased plant growth in each treatment is presented in table 1, including data on plant height, pseudo-stem length, and the number of leaves.

Table 1. Characteristics of plant growth at seven weeks after planting.

\begin{tabular}{cccc}
\hline Treatment & Plant height & $\begin{array}{c}\text { Pseudo } \\
\text { Long Rods }\end{array}$ & $\begin{array}{c}\text { Number of } \\
\text { leaves }\end{array}$ \\
\hline M0K0 & $50.43^{\mathrm{ab}}$ & $8.28^{\mathrm{a}}$ & $6.43^{\mathrm{a}}$ \\
M0K1 & $45.10^{\mathrm{b}}$ & $7.37^{\mathrm{b}}$ & $6.20^{\mathrm{a}}$ \\
M0K2 & $52.27^{\mathrm{a}}$ & $7.89^{\mathrm{ab}}$ & $6.40^{\mathrm{a}}$ \\
M1K0 & $52.96^{\mathrm{a}}$ & $7.56^{\mathrm{ab}}$ & $6.60^{\mathrm{a}}$ \\
M1K1 & $55.42^{\mathrm{a}}$ & $7.64^{\mathrm{ab}}$ & $6.60^{\mathrm{a}}$ \\
M1K2 & $51.42^{\mathrm{ab}}$ & $7.71^{\mathrm{ab}}$ & $5.97^{\mathrm{a}}$ \\
HSD 5\% & 6,83 & 0,75 & 0,75 \\
\hline
\end{tabular}

The results of this study indicate that the plant height character in the microbial treatment with NPK $50 \%$ of the recommendations (MIKI) can show the best plant height character even though the results of statistical tests do not show any differences with some other treatments, whereas the treatment without microbes with NPK $50 \%$ from the recommendation (M0K1) shows the lowest plant height and no difference with treatment without microbes and without NPK (M0K0). On the character of pseudo-stem length treatment without microbes with NPK 50\% fertilizer showed the lowest pseudo-stem height, while for the character of the number of leaves between the test treatments did not show differences.

The results of this study indicate the influence of NPK fertilizer application and the addition of biological microbes to the height characteristics of garlic plants, the addition of microbial treatment with NPK $50 \%$ of the recommendation (MIKI) can increase the growth of garlic plant height by 10 percent compared to negative control treatments (without NPK and microbes) whereas when compared with treatments without microbes with NPK 50\% (M0K1) it can increase plant height growth by $22.88 \%$.

The increase in plant height in the treatment of microbial consortia and 50\% NPK fertilizer is the result of the availability of nutrients needed by the garlic plants. Even though the dose of NPK fertilizer given is only $50 \%$ of the recommended dose, the microbial consortium can compensate for the nutrient requirements that plants need for vegetative growth. Suprapto et al. [7] states that onion plants require the availability of macronutrients, especially nitrogen $(\mathrm{N})$, phosphorus (P) and potassium (K) insufficient and balanced amounts, both from inorganic fertilizers and organic fertilizers. Fertilization with a microbial consortium can provide nutrients both macro and micro and help improve the development of soil microorganisms which then regulate nutrient availability. This is reinforced based on the results of research Kalay et al. [4], which states that the microbial consortium can increase plant height growth with nitrogen fixation bacterial content by providing $\mathrm{NH}_{3}$ and subsequently converted to $\mathrm{NH}^{4+}$ and $\mathrm{NO}^{3-}$. Nitrogen, phosphorus, and potassiumnutrient needs that are fulfilled can affect the total microbial population in the soil. According to Agustian et al. [8], an increasing microbial population indicates that the supply of food or energy needed by microbes for survival has been fulfilled, therefore the production of phytohormones such as auxins and cytokines will increase and affect the growth of garlic plants. Increased auxin production will have an impact on performance which stimulates cell extension and stimulates the formation of flowers and seeds in plants.

The provision of microbial and NPK consortium also affects the growing ability of garlic (Figure 1), the percentage of the growing power of each test treatment is presented in the figure below.

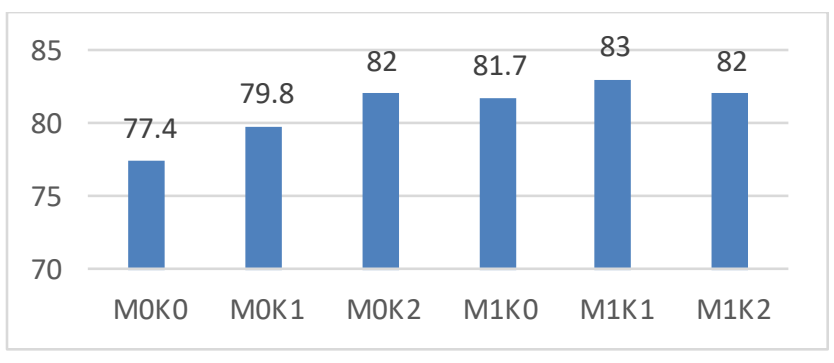

Figure 1. Percentage of the growing power of garlic 
The results of this study indicate the MOK0 treatment (without microbes and NPK fertilizer) showed the lowest growing power of $77.4 \%$ while the microbial treatment with $50 \%$ NPK (M1K1) showed the highest growth power of $83 \%$, this indicated the MIKI treatment was able to increase the ability to grow garlic and showed the best treatment compared to other treatments. One of the low growth power caused by the intensity of plant diseases, namely fusarium wilt disease. The intensity of fusarium disease in the treatment without a microbial consortium is higher than in the treatment of a microbial consortium. According to Yanti [9], 2 inhibitory mechanisms can be carried out by a microbial consortium, namely direct inhibition by inhibiting the growth of plant pathogens through antagonism mechanism, among the microbes contained in the microbial consortium some microbes are antagonistic and can produce antibiotics such as Pseudomonas that produce antibiotics such as phenazines, pyrolnitrin, pyocyanin, phloroglucinol and pseudomonic acid [10]. The next mechanism is indirect inhibition, by stimulating plant growth by facilitating the uptake of nutrients in the environment such as nitrogen retention from the air or by producing growth hormones such as auxin, gibberellins, and cytokines so that plant growth is better and more resistant to disease.

Besides the presence of microbial content, the availability of macronutrients such as nitrogen $(\mathrm{N})$, phosphorus (P), and potassium (K) also affect the resistance of garlic plants to the percentage of mortality. The balance of nutrients from NPK fertilizer when it is reached will have an impact on the hardness of plant tis sue so that plants become stronger and more resistant to disease attacks. The effect of NPK fertilizer treatment and the addition of a microbial consortium to garlic yields is shown in Table 2.

Table 2. Garlic Harvest Results

\begin{tabular}{cc}
\hline Treatment & Harvest Yield $(\mathrm{Kg})$ \\
\hline M0K0 & 1.35 \\
M0K1 & 1.12 \\
M0K2 & 1.47 \\
M1K0 & 1.78 \\
M1K1 & 1.83 \\
M1K2 & 1.36 \\
\hline
\end{tabular}

The results of this study showed that treatment with the addition of microbes with NPK 50\% (M1K1) gave the highest yield compared to other treatments. The addition of a microbial consortium with $50 \%$ NPK could increase the yield of garlic by $35.6 \%$ compared to yields without a microbial consortium and NPK. Razzak et al. [11] stated that generally the yield and yield of high garlic bulbs were due to the effects produced by non-symbiotic N2 binding bacteria on the morphology or physiology of the root system. Azotobacter and Azospirillum contained in the microbial consortium produce IAA, gibberellins, and cytokinins in sufficient quantities, as well as synthesizing some vitamins. This is in line with Zaki et al. [12] which states that the addition of a microbial consortium can increase the surface area and root length to increase the branching of the root hairs, then there is a major increase in the absorption of nutrients and water adsorption from the soil which ultimately results in larger plant tubers.

\section{Conclusion}

The addition of a microbial consortium and NPK fertilizer can affect the growth of plant height, the percentage of plant growth, and yield of garlic plants. The addition of a microbial consortium and the use of NPK $50 \%$ of the recommendations were able to show the best results both in terms of plant height growth, percentage of plant growth, and yield of garlic compared to other test treatments.

We would like to thank all those who helped with the completion of this research activity including Kujang Fertilizer who has facilitated the availability of a microbial consortium and NPK fertilizer and UIN students (sisters Erna and Anna) who helped a lot in carrying out this research.

\section{References}

1. A. Hassan, Improving Growth and Productivity of Two Garlic Cultivars (Allium sativum L.) Grown under Sandy Soil Conditions. Middle East Journal of Agriculture Research. 4(2): 332 - 346, (2015)

2. FAO. Rankings Countries by Commodity. www.FAO.org/faostat/en/\#rankings/countries_by_ commodity/.(2016)

3. A.H. Kusuma, M. Izzati, \& E. Saptiningsih. Pengaruh Penambahan Arang dan Abu Sekam dengan Proporsi yang Berbeda terhadap Permeabilitas dan Porositas Tanah Liat serta Pertumbuhan Kacang Hijau (Vigna radiate L). Buletin Anatomi dan Fisiologi: 1-9, (2013)

4. A.M. Kalay, R. Hindersah, A. Talahaturuson, \& A.F. Langai. 2016. Efek Pemberian Pupuk Hayati Konsorsium terhadap Pertumbuhan dan Hasil Tanaman Sawi (Brassica juncea L.). Jurnal Agroekoteknologi. 8(2): 131 -138, (2016)

5. T. Simarmata, B. Joy, \& N. Danapriatna. Peranan Penelitian dan Pengembangan Pertanian pada Industri Pupuk Hayati (Biofertilizers). Prosiding Seminar Nasional Teknologi Pemupukan dan Pemulihan Lahan Terdegradasi BBSDLP. 29 Juni: 1-14, (2012)

6. A. Wahyudin, F.Y. Wicaksono, A.W. Irwan, Ruminta, \& R. Fitriani. Respons Tanaman Kedelai (Glycine max) Varietas Wilis Akibat Pemberian Berbagai Dosis Pupuk N, P, K dan Pupuk Guano 
pada Tanah Inceptisol Jatinangor. Jurnal Kultivasi. 16(2): 333 - 339, (2017)

7. A. Suprapto, M. Astiningrum, \& H. Rianto. Optimalisasi Dosis pupuk NPK dan Pupuk Organik Cair untuk Produksi Bawang Merah di Lahan Pasca Erupsi Merapi, (2018)

8. N. Agustian., L. Maira, \& O. Emalinda. Rhizobakteria Penghasil Fitohormon IAA Pada Rhizosfir Tumbuhan Semak Karamunting, Titonia dan Tanaman Pangan. Jurnal Solum. 7(1): 49 - 60, (2010)

9. F. Yanti. Aplikasi Konsorsium Bakteri terhadap Pertumbuhan dan Hasil Pada Beberapa Varietas Padi. Skripsi. Universitas Jember. Jember, (2015)
10. P.M.B. Iskandar \& S. Purwantisari. Kemampuan Antagonisme Pseudomonas sp. dan Penicillium sp. Terhadap Cercospora nicotianae In Vitro. Jurnal Biologi. 7(3): 1 - 7, (2018)

11. H.S.A. Razzak, \& G.A. El- Sharkawy. Effect of Biofertilizer and Humic Acid Applications on Growth, Yield, Quality and Storability of Two Garlic (Allium sativum L.) Cultivars. Asian Journal of Crop Science. 5(1): 48 - 64, (2013)

12. H.E.M. Zaki, H.S.H. Toney, \& A.R.M. Elraouf. Response of two Garlic Cultivars (Allium sativum L.) to Inorganic and Organic Fertilization. Nature and Science. 12(10): 52 - 60, (2014) 